\title{
Original contributions
}

J. Perinat. Med.

3 (1975) 89

\section{Effects of standing position on spontaneous uterine contractility and other aspects of labor}

\author{
C. Méndez-Bauer*, J. Arroyo, C. Garcia Ramos, A. Menéndez, M. Lavilla, \\ F. Izquierdo, I. Villa Elízaga**, J. Zamarriego***
}
Depts. of Obstetrics and Neonatology of the Maternidad "Santa Cristina", Madrid, Spain
Ministry of Education and Sciences, Scientific Research Council

It has been shown that changing the maternal position during labor may have an influence on uterine contractility.

Williams 1952 [9] reported on one patient, whose contractions became more intense when she was in sitting position, using internal tocography. Two years later, von LoRAND and Pogany [8], using external tocography, claimed that the recumbent position increased uterine contractions. These observations were made during spontaneous labor, in nulliparae with intact membranes. Bösch, IKLE and KÄSER 1954 [4] and Caldeyro et al. 1960 [6] demonstrated, that uterine contractions were stronger and less frequent when the patient lay on her side (left or right), than when she was supine.

When evaluating the effects of maternal position on uterine contractility, it should be recalled that several other. factors including parity, condition of the membranes and medication given to the mother, may also influence spontaneous uterine contractility and labor.

The first objective of this paper is to study the effect of standing position on spontaneous uterine contractility, when these factors are taken into account. Furthermore the influence of the maternal position on the pain produced by contractions, comfort of the patient and duration of labor have not been studied, in our knowledge. An additional aim is to study the effects of standing position on the duration of labor, pain produced by uterine contractions and comfort

\section{Curriculum vitae}

Carlos Mendez-Bauer was born in Montevideo (Uruguay) in 1930. He completed bis studies there and graduated as Doctor in Medicine at the Faculty of Medicine, University of the Republic, Montevideo (Uruguay). In 1952 be joined the Service of Obstetrical Pbysiology, directed by R. Caldeyro-Barcia. Since that time be has become interested in uterine pbysiology, endocrinology of labor, and pbysiology of the fetus and newborn. In 1966 be was appointed chief of the Service of Obstetrical Pbysiology, Montevideo (Uruguaj'). He moved in 1969 to USA, where be remained for one year as Associate Professor of Obstetrics and Gynecology and Physiology at the University of Minnesota. Returning to Montevideo be participated in the activities of the Latin American Center of Perinatology and Human Development (CLAP), institution sponsered by P. A. H. O. (WHO). In 1973 be joined the Maternidad Santa Cristina, Madrid, Spain, to develop a program of care and research in Perinatology in cooperation with the Departments of Obstetrics, Gynecology' and Neonatology. $H e$ has published several papers and articles in connection with perinatal problems.

of the patient since, to our knowledge these have not hitherto been studied.

* Chief, Research Department.

** Chief, Department of Neonatology \& Perinatal Medicine.

*** Director and Chief, Department of Obstetrics and Gynecology. 


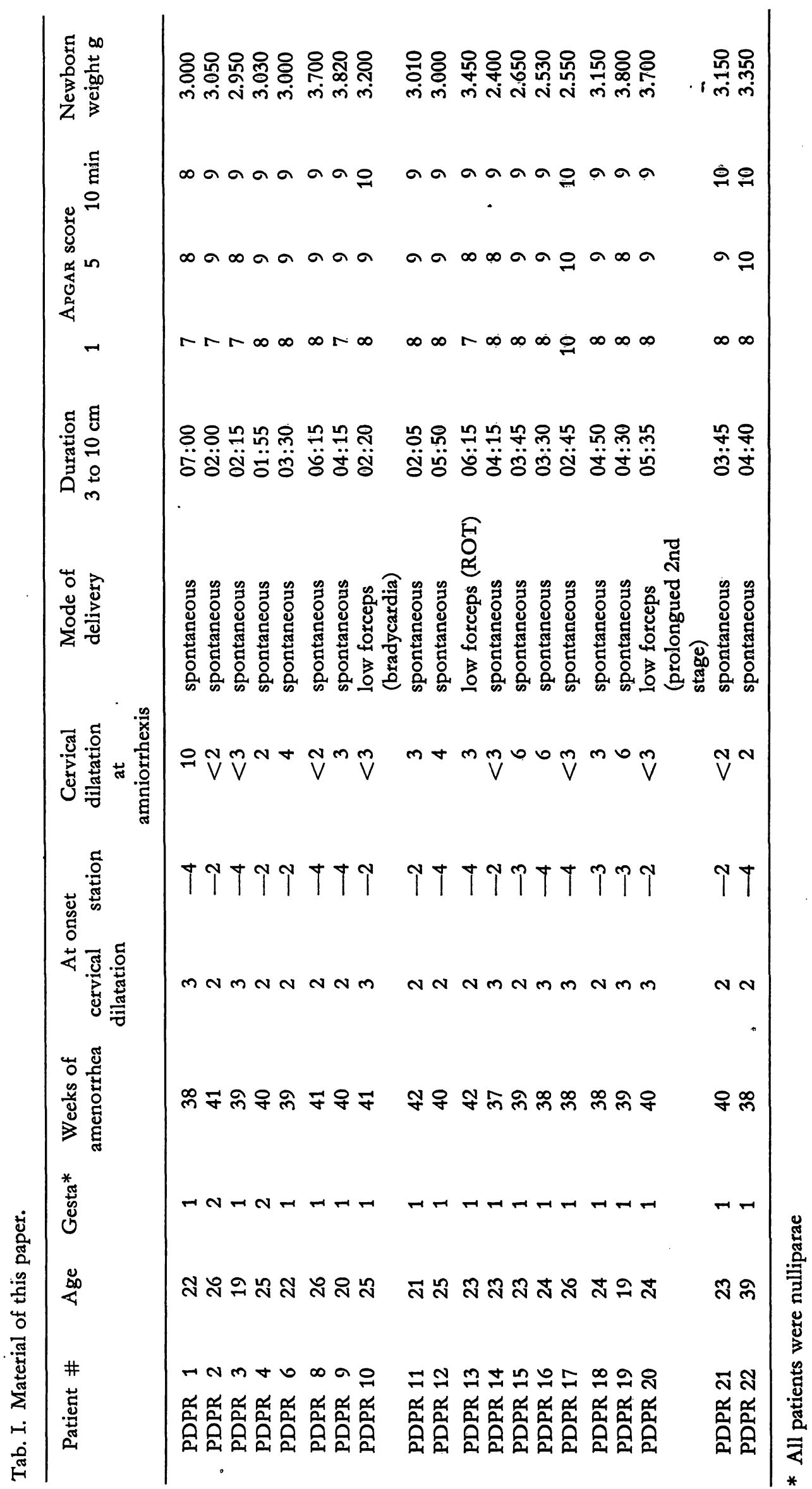




\section{Material and methods}

Twenty normal spontaneous labors with vertex presentation were studied. This group was selected at random from among the normal pregnant nulliparae that came to deliver at our Hospital. They were told that their position would be changed during labor, but were not told what effect this change in position might have. No oxytocics, sedatives, nor any other medication, were given to the mother during labor. Additional clinical information is presented in Tab. I.

The study began when spontaneous uterine contractions were present and cervical dilatation was at $2-3$ centimeters. At this time recording of uterine contractility was started, by placing an open tip catheter into the uterus, either intraor extra-amniotically, according to the condition of the membranes (ruptured or intact). The degree of cervical dilatation at the time of membrane ruptured is shown in Tab. I. The saline filled catheter was connected to a pressure transducer (8021A Hewlett-Packard Cardiotocograph). The system was frequently flushed to avoid recording artifacts. The pressure transducer was attached to the maternal abdomen close to the fundus of the uterus to roughly compensate for the changes in the "zero level" occurring when the patient moved from supine to standing or viceversa. The rationale of this modification to the standard technique of attaching the manometer to the monitor is discussed elsewhere [2].

\subsection{Method of procedure}

The patients were asked to change from supine to standing position or viceversa at intervals of 30 minutes. The first position was selected at random. They were allowed to walk or rest in a chair for short intervals during the standing period, if they wished so. A vaginal examination was performed - always by the same observer at the onset of the study and at the end of each period of 30 minutes. The characteristics of the cervix were carefully evaluated. The study was continued until full cervical dilatation was attained. The second stage was managed with local anesthesia to the perineum and the patient lying in supine position. General anesthesia or analgesia was not used, except for operative deliveries. As much as possible, the environmental conditions were kept constant throughout labor. At the end of the study, the patients were asked to assess the pain caused by uterine contractions in each position, and to state which position was the most comfortable for her.

Fetal heart rate was also monitored, either by ultrasound or by ECG using a scalp electrode and the above mentioned monitoring equipment. The newborns were examined by a neonatologist, and the Apgar score was performed at the 1st, 5 th and 10th minute of life. The corresponding scores are showed in Tab. I.

\subsection{Quantitative analysis of the tracings of uterine contractility $[5,6]$}

1. Intensity of the contractions was measured in $\mathrm{mm} \mathrm{Hg}$ from the baseline (tonus) to the peak of each uterine contraction. Only contractions having an intensity over $5 \mathrm{~mm} \mathrm{Hg}$ were considered.

2. Frequency of the contractions was measured by the reciprocal of the time elapsed from the peak of the contraction to the peak of the preceding one. The result was expressed as the number of contractions per 10 minutes. To calculate the frequency, only contractions having more than $5 \mathrm{~mm} \mathrm{Hg}$ of intensity were considered. 3. Uterine activity was calculated multiplying the intensity times the frequency of the contractions. The result was expressed as $\mathrm{mm} \mathrm{Hg}$ per 10 minutes, or Montevideo Units.

4. Uterine tonus was not analyzed in the present study since the changes in maternal position made the measurement inaccurate.

\subsection{Statistical analysis of the tracings of uterine contractility}

1. Intensity of contractions. For every patient, the values of intensity of all the contractions recorded in each maternal position, were averaged. The corresponding two mean values (patient in supine or standing position) were compared by a Student's test $(2 \alpha)$. The significance of the difference between the means found in each case are shown in Fig. 3. A value of $p<0.05$ was 
considered as significant. Those cases showing a significant increase in the intensity of the contractions, when changing the patient from supine to standing position, were considered as "positive". When the intensity of contractions did not change or decreased significantly (only patient \# 17) the observation was considered as "negative". Each patient was thus classified as positive or negative. The series was continued until the ratio of positive and negative observations reached a significant level $(p<0.05)$ by a sequential analysis. This criteria was employed to determine the size of the sample (20 patients in total).

2. Frequency of uterine contractions - uterine activity. The method of statistical analysis used for these parameters was similar to that of intensity. But no sequential test was applied since their changes were not consistent in the succesive observations.

\section{Results}

\subsection{Uterine contractility}

The effects of changing' 'maternal position on uterine contractility will be discussed separately for each one of the parameters studied.

\subsubsection{Intensity}

The intensity of contractions increased significantly $(p<0.05)$ in the standing position in fifteen out of the twenty patients studied. It did not change significantly in four patients and decreased significantly in one (\#17) (Fig. 3). These results were evaluated patient by patient by sequential analysis. The proportion of positive versus negative observations, found for the group of twenty patients, was significant to a level of $p<0.05$. Figures 1,2 and 6 are typical examples of the effects of changing position on uterine contractility. In general, the intensity of

POPR $3 \longdiv { 4 3 }$

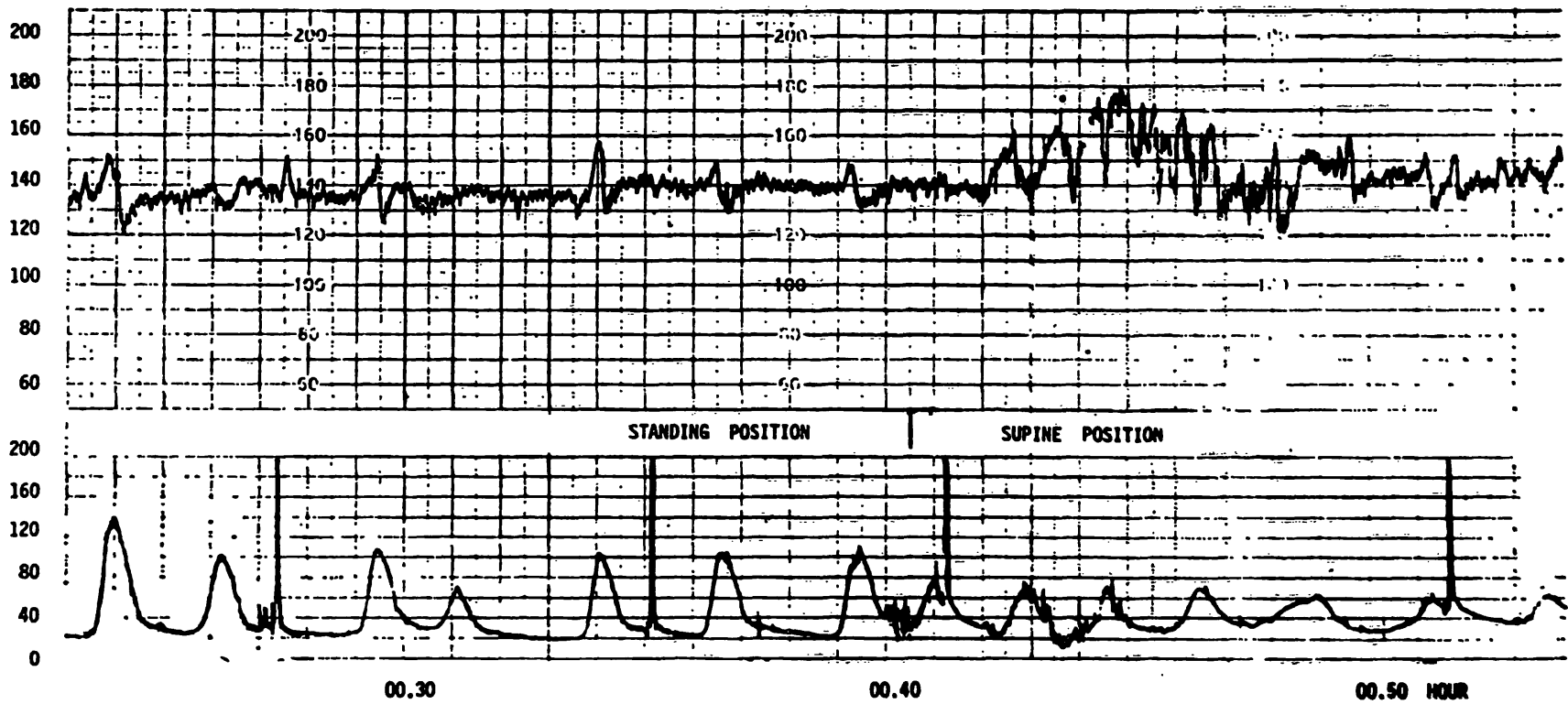

Fig. 1. Original tracing obtained in a normal pregnant 19 years old patient. Vertex presentation. Gesta I, Para 0,39 th week of amenorrhea. Membranes were spontaneously ruptured at the onset of the study (hour 00:00). At hour 00:40, the cervical dilatation was $5 \mathrm{~cm}$ and presentation at station -1 .

Spontaneous delivery occurred at hour 02:15. Female newborn; weight $2.950 \mathrm{~g}$. Apgar score 7,8 and 9 at the 1 st, 5 th and 10th minute of life. Note that the intensity of contractions was higher and the frequency was lower in standing position.

Also, contractions appeared better coordinated in this position. All changes developed rapidly.

At hour 00:42, fetal $\mathrm{pH}$ was 7.37 and maternal $\mathrm{pH}$ was 7.48 .

It took 2 hours and 15 minutes to dilate from 3 to 10 centimeters (Tab. I). (Same patient as in Fig. 2.) 


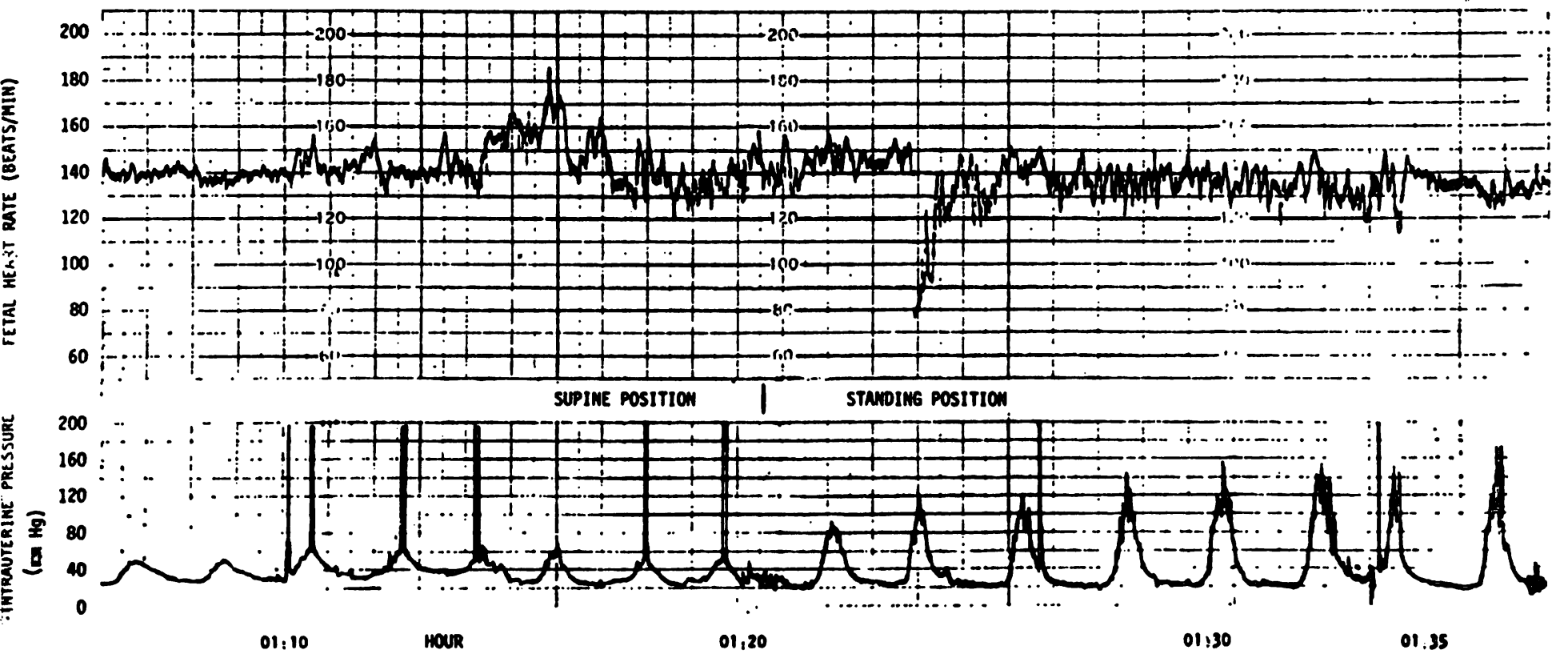

Fig. 2. Same patient as in Fig. 1. At hour $01: 20$, the cervix attained $9 \mathrm{~cm}$ dilatation and the presentation was in station 0 . When the mother changed from supine to standing position, uterine contractions became more intense, less frequent and better coordinated. The patient reported equal pain with contractions in both positions, although they were remarkably more intense in standing than in supine position. Fetal $\mathrm{pH}$ at hour 01:15 was 7.37.

Note the frequent flushings of amniotic pressure recording, performed in supine position, to corroborate the reliability of the tracing. Bearing down efforts appeared at hour 01:33. Delivery occurred at hour 02:15 (see legend of Fig. 1).

contractions diminished when the patient moved from standing to supine position (Fig. 1). The opposite effect was seen when the patients moved from supine to standing position (Fig. 2, 6). The changes in the intensity of contractions were very rapid, involving one or two contractions to develop and they lasted until maternal position was changed again.

\subsubsection{Frequency}

Significant changes were found in only seven patients. In six of them, the frequency of contractions diminished when the patient changed from supine to standing position and it increased in the remaining one (\#17). The twelve other patients had no significant modifications in the frequency of the contractions, in relation to their position (Fig. 4). Figures 1 and 2 illustrate one of the six patients whose frequency of contractions diminished significantly in standing position. The changes in the frequency also developed as rapidly as those of the intensity.

\subsubsection{Uterine activity}

This increased significantly in half of the patients studied (Fig. 5) as a consequence of the combined effect of the changes in intensity and frequency of contractions in each case.

\subsubsection{Coordination}

Although it is difficult to evaluate this parameter objectively, an analysis of the tracings indicated that irregularities in the shape, rhythm and intensity of the contractions were more frequent in supine than in standing position (Figs. 1, 2, 6).

Comparison between the patterns of uterine contractility recorded in the two different positions studied suggested that, according to Caldeyro, Alvarez and Reynolds [5], uterine contractions were better coordinated in the standing than in the supine position.

Thus, in the standing position uterine contractions showed a consistent increase in their intensity compared to the activity in the supine position. 


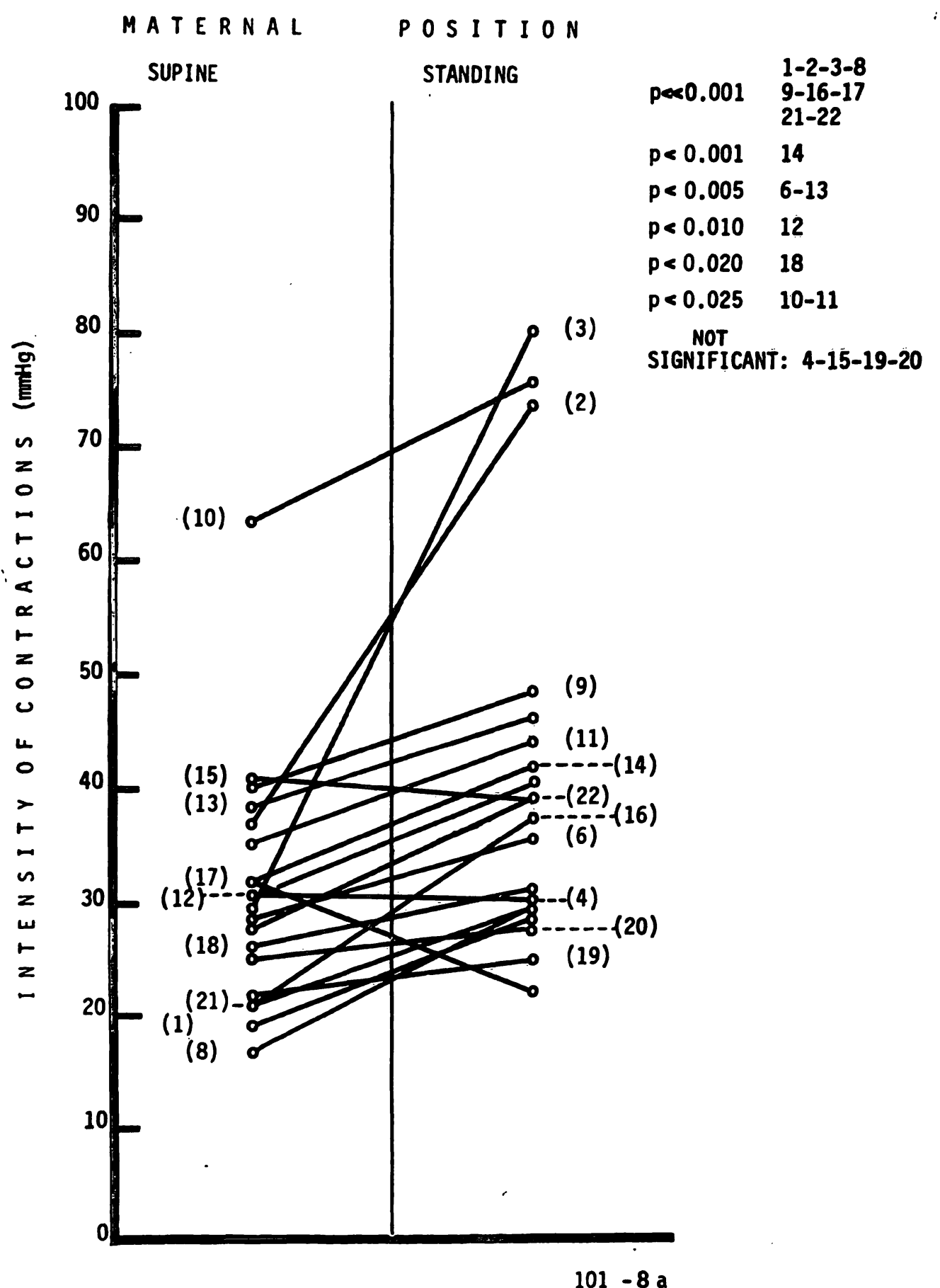

Fig. 3. Statistical analysis of the intensity of contractions, comparing supine vs. standing position.

Each bar represents the averages of intensity of the contractions ( $\mathrm{mmHg}$ ) with the patient in supine or standing positions. The bracketed figures correspond to the ordinal number of each patient.

The individual significance of the differences of the mean is shown at the upper right, for each observation. In cases $4,15,19$ and 20 , the intensity of contractions did not change significantly $(p>0.05)$. In observation \# 17 the intensity diminished significantly when standing. In the remaining 15 observations, the intensity was significantly greater, when the patient was in the standing position $(\mathrm{p}<0.05)$. The proportion of patients whose intensity increased is significant ( $p<0.05)$. Modified after Arroyo et al. [3]. 


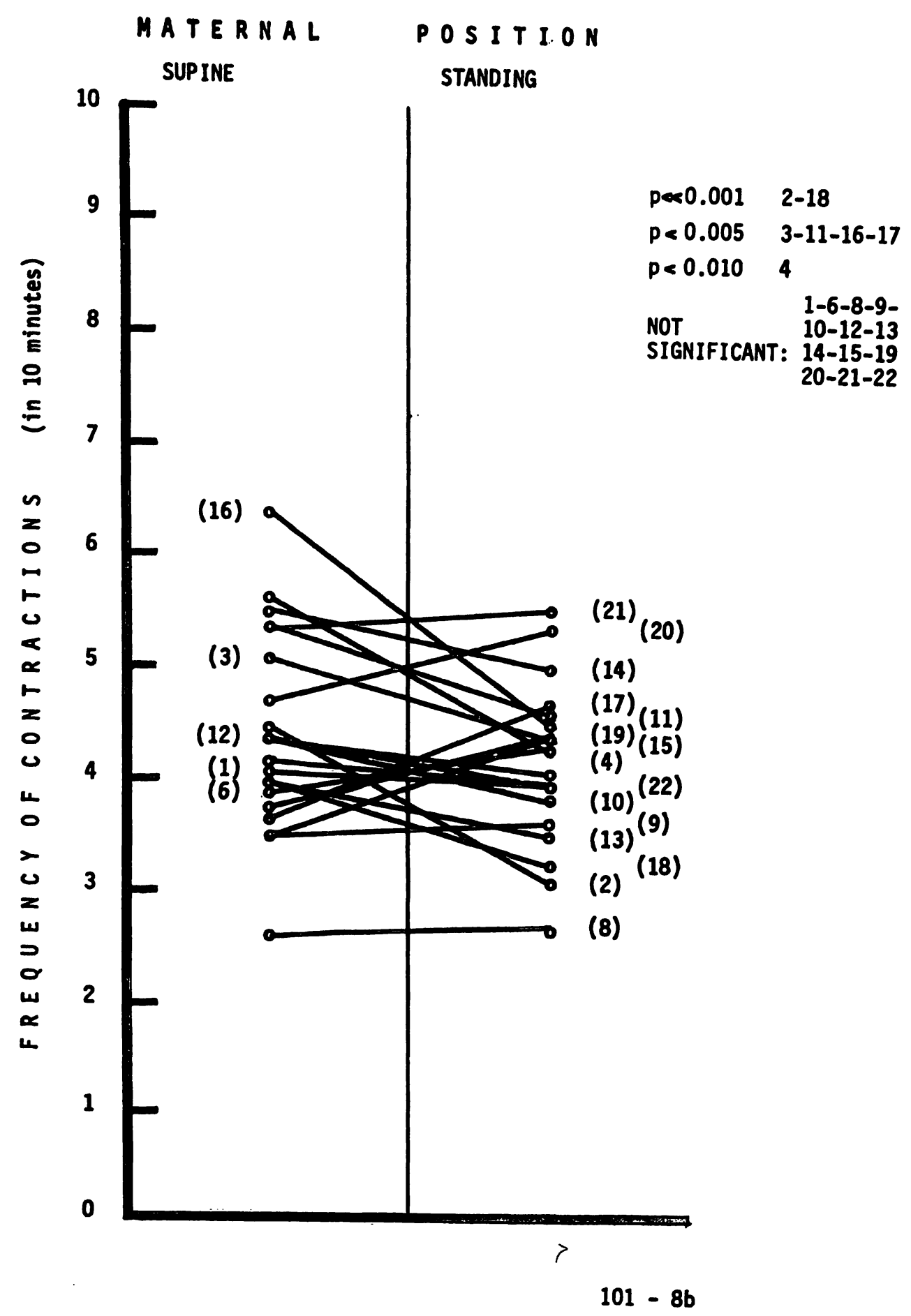

Fig. 4. Statistical analysis of the frequency of contractions, comparing supine vs. standing position (same representation as in Fig. 3). The frequency is measured as the number of contractions present in ten minutes. Thirteen observations showed no significant differences in the frequency of contractions between both positions. In the remaining the frequency was significantly lower in standing position (excluding patient \# 17, whose frequency increased significantly in this position). Modified after Arroyo et al. [3]. 


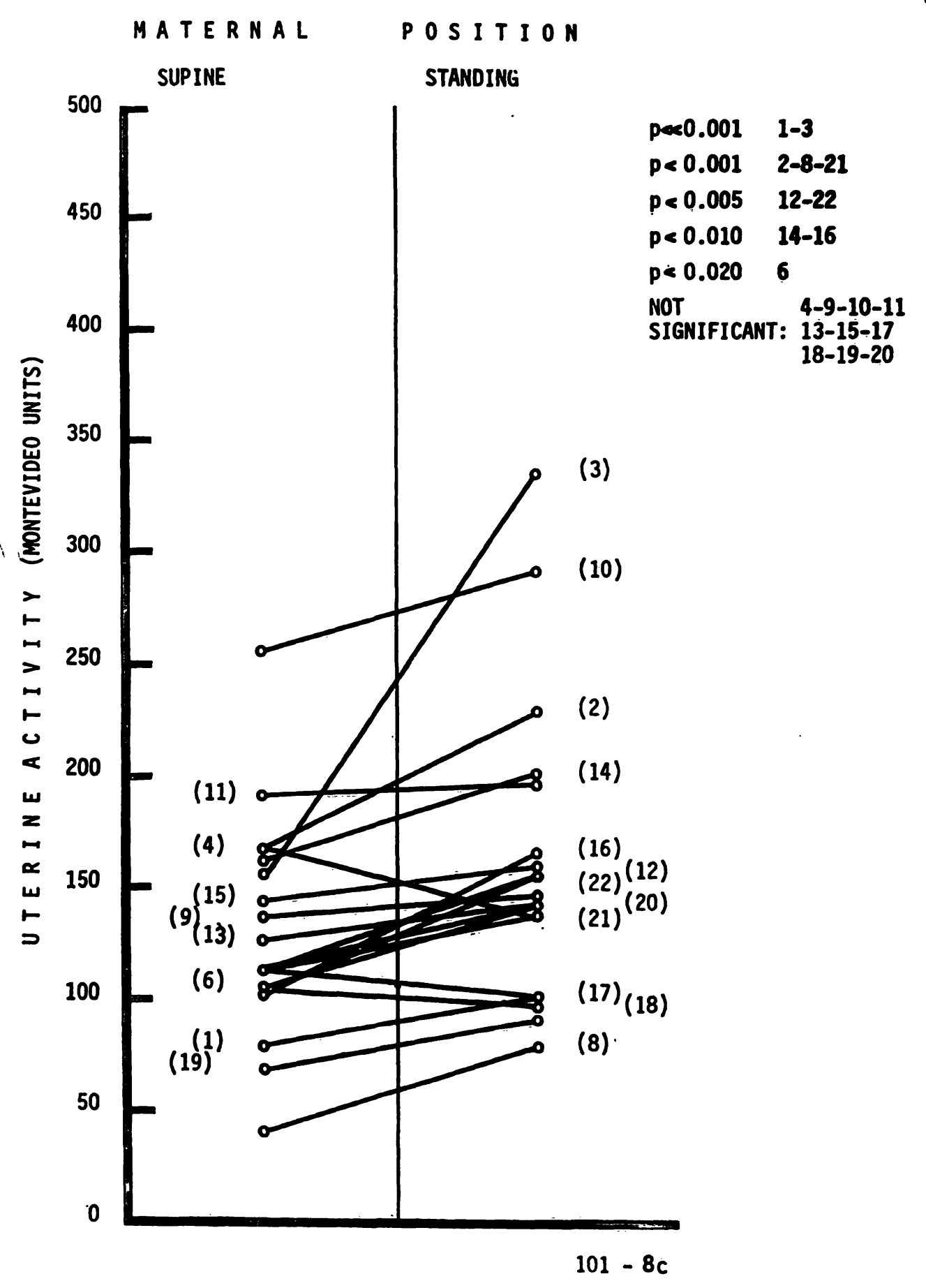

Fig. 5. Statistical analysis of the uterine activity of contractions comparing supine vs. standing position (same representation as in Figs. 3 and 4).

The uterine activity is measured in Montevideo Units, i. e.: the intensity in $\mathrm{mmHg}$, times the frequency of contractions (in 10 minutes). It was significantly greater in standing position in 10 out of the 20 patients studied, as a consequence of the combined effects on the intensity and frequency of the contractions. In the other patients uterine activity did not change significantly. Modified after Arroyo et al. [3]. 


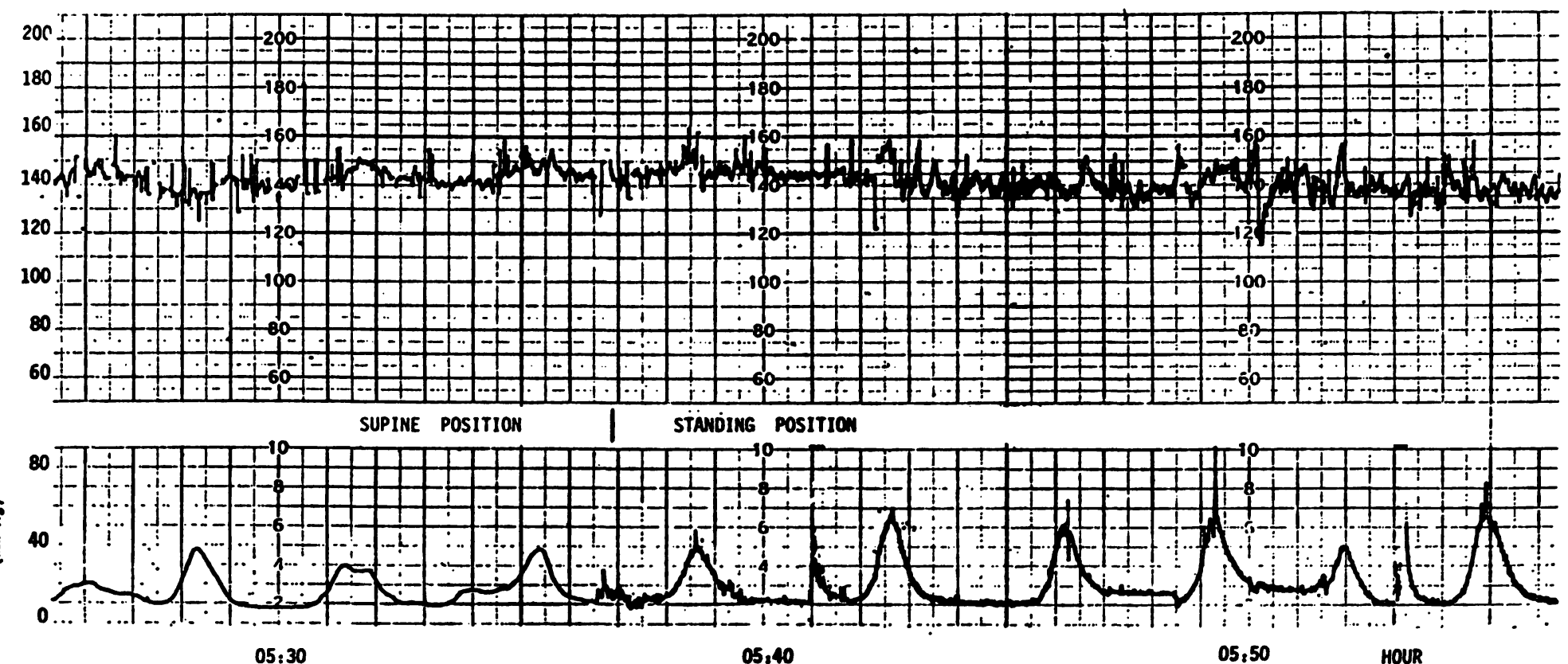

Fig. 6. Original tracing obtained in a normal pregnancy. Twenty four years old patient, Gesta I, Para 0 . Thirty eight weeks of amenorrhea. Vertex presentation. Recording started at hour 00:00, at $2 \mathrm{~cm}$ cervical dilatation and station - 4. Membranes were artificially ruptured at hour 02:10, and, at hour 03:06, the presentation was at station -3 and cervical dilatation was $3 \mathrm{~cm}$. At the change in position, the cervix was $5 \mathrm{~cm}$ dilated and presentation was at station - 2. The spontaneous delivery of a female $(3.150 \mathrm{~g})$ occurred at hour 07:55. A loop of cord was found around fetal neck. Apgar score 8,9,9, at minutes 1st, 5th and 10th of life. Note the increase in the intensity of contractions in standing position as well as less irregularities, suggesting a better coordination. The duration of labor, from $3 \mathrm{~cm}$ to delivery was $04: 50$ hours.

Frequency of contractions remained unchanged or tended to diminish. The combined effect of both changes resulted in an increased uterine activity in fifty per cent of the patients. Contractions appeared better coordinated in standing position.

\subsection{Comfort and pain relative to position}

Nineteen out of the twenty patients reported greater comfort when standing than in supine position (Tab. II, left side). Fifteen reported less pain with uterine contractions in the standing position. Of the remaining five, one (\# 22) reported more pain in standing position whereas the other four felt no difference in either position.

It should be noted that three out of the four patients who felt similar pain (with contractions) in both positions were those who had the most pronounced increase in the intensity of their contractions, when they changed to the standing
Tab. II. Comfort and pain to position.

\begin{tabular}{lll}
\hline & $\begin{array}{c}\text { More comfort of } \\
\text { the patient }\end{array}$ & $\begin{array}{c}\text { Less pain with } \\
\text { contractions }\end{array}$ \\
\hline PDPR 1 & standing & standing \\
PDPR 2 & standing & no difference \\
PDPR 3 & standing & no difference \\
PDPR 4 & standing & standing \\
PDPR 6 & standing & standing \\
PDPR 8 & standing & standing \\
PDPR 9 & standing & standing \\
PDPR 10 & standing & standing \\
PDPR 11 & standing & standing \\
PDPR 12 & standing & standing \\
PDPR 13 & standing & no difference \\
PDPR 14 & standing & standing \\
PDPR 15 & standing & standing \\
PDPR 16 & standing & no difference \\
PDPR 17 & standing & standing \\
PDPR 18 & standing & standing \\
PDPR 19 & standing & standing \\
PDPR 20 & standing & standing \\
PDPR 21 & standing & standing \\
PDPR 22 & no difference & supine \\
\hline
\end{tabular}


Tab. III. Duration of labor.

\begin{tabular}{|c|c|c|}
\hline & $\begin{array}{l}\text { CrbiLs (1972) [6] } \\
\text { multiparae } \quad \text { nulliparae }\end{array}$ & $\begin{array}{c}\text { ours } \\
\text { nulliparae }\end{array}$ \\
\hline $\begin{array}{l}\text { duration of } \\
\text { labor from } \\
3 \text { to } 10 \mathrm{~cm}\end{array}$ & $3 \mathrm{hs} 30 \mathrm{~min} 6 \mathrm{hs} 20 \mathrm{~min}$ & $\begin{array}{c}3 \text { hs } 55 \mathrm{~min} S D \\
1 \mathrm{~h} 40 \mathrm{~min}\end{array}$ \\
\hline
\end{tabular}

position (\# 2, \# 3 and \# 16, Fig. 3). Thus, the standing position seemed to be associated with less pain caused by uterine contractions and with more comfort to the patient during the dilatation period.

\subsection{Duration of labor}

This was measured from 3 to $10 \mathrm{~cm}$ of cervical dilatation. The average duration has been three hours and fifty five minutes (S.D. $1 \mathrm{~h} 40 \mathrm{~min}$ ) (Tab. III).

\subsection{Complications}

No complications which could be accounted to the standing position occurred. Three patients complained about mild dizziness when standing. This disappeared after sitting for a few minutes. Frequently, the patients developed only a slight tachycardia in the standing position. No cord prolapse occurred, even though, in most instances, membranes were ruptured early in labor (Tab. I).

One fetus (\# 10) developed signs of distress at the end of the first stage and in two patients the second stage was prolonged.

These three fetuses were delivered by a low forceps. The APGAR score of the newborns averaged 7 or higher (Tab. I).

\section{Discussion}

The effects of lateral position on uterine contractility have been carefully assessed [6]. Comparing this information with the present results, it can be said that the changes in intensity and coordination of contractions found when the patient is standing, are rather similar to those in lateral position. The changes in the frequency of con- tractions are more consistent in lateral [6] than in standing position. Information on the duration of labor, pain with contractions and comfort of the patient on lateral position is less complete. The average duration of labor in this series from 3 to $10 \mathrm{~cm}$ of cervical dilatation was $3 \mathrm{~h} 55 \mathrm{~min} \pm 1 \mathrm{~h}$ $40 \mathrm{~min}$ (S. D.). This seemed to be shorter than usual, according to the standard clinical experience in nulliparae. The present results have been compared with those of CiBILs [7]. From this comparison (Tab. III), it can be seen that the average duration of the labors of the present series is much shorter than that observed in CibiLs' series for nulliparae, being closer to the multiparaes than to the nulliparaes. This comparison suggests that the periods of standing position could be a factor contributing to the shorter duration of labor.

As to the comfort of the patient and the pain produced by contractions, both improve consistently in standing compared to supine position. It should be emphasized that the standing position did not have any undesirable effect on the fetus or newborn (Tab. I) in this group of patients, although it should be recalled that the obstetrical conditions were favourable to prevent them.

The physiological mechanisms responsible for the changes in uterine contractility, perception of pain caused by contractions and perhaps shortening of labor, observed when the patient is in standing position, are unknown [8].

At all events, there appear to be no clear arguments against the use of standing position during labor, provided some obstetrical conditions are fulfilled (vertex presentation, engagement of fetal head, etc.). Under these conditions, standing position proved to be harmless. In nulliparae it increased the intensity of contractions, improved their coordination and possibly shortened the duration of labor. Furthermore, the patients felt comfortable and had less pain with contractions when standing. Hence it could be concluded that some benefit should result from a more frequent use of standing position in clinical obstetrics. 


\section{Summary}

The aim of this paper has been to compare the uterine contractility, pain produced by contractions and comfort of the patients between standing and supine position.

The study has been performed in twenty normal nulliparae who were changed from supine to standing position and viceversa at intervals of approximately thirthy minutes. Intrauterine pressure and fetal heart rate were continuously monitored. Cervical dilatation was evaluated every thirty minutes. No medication was given to the patients. They were asked to assess the pain produced by uterine contractions in each one of both positions and which was the more comfortable.

It has been found:

1. That the intensity of contractions was significantly higher in fifteen out of the twenty patients (Figs. 1, 3) in standing position.

2. Frequency of contractions diminished significantly in one third of the patients (Fig. 4).
3. Uterine activity increased significantly in half of them (Fig. 5).

4. Consistently, less pain accompanied uterine contractions in standing position (Tab. II).

5. Patients reported more comfort in this position (Tab. II).

The average duration of labor was $3 \mathrm{hrs} 55 \mathrm{~min}$. This duration is short, compared with standard clinical experience and with published data. No complications occurred, by the use of standing position during labor, on the mother or fetus. The physiological mechanisms responsible for the above mentioned effects of standing position are unknown.

It is concluded that there are no clear arguments against the use of standing position during labor and that this position should be used more frequently in clinical obstetrics, provided obstetrical conditions are similar to those reported in this paper.

Keywords: Amniotic pressure, complications of labor, duration of labor, maternal position, pain with contractions, uterine contractility, spontaneous labor.

\section{Zusammenfassung}

Untersuchungen über den Einfluß des aufrechten Standes auf die spontane uterine Wehentätigkeit und andere Geburtsfaktoren

Es konnte bewiesen werden, daß unterschiedliche mütterliche Haltungen einen Einfluß auf die uterine Kontraktilität und andere Faktoren der Wehentätigkeit haben können $[4,6]$. Die Einflüsse der aufrechten Körperhaltung wurden bisher nicht ausreichend beachtet. Das Anliegen dieser Arbeit war es, die uterine Kontraktionsbereitschaft, den weheninduzierten Schmerz und das Wohlbefinden der Patientin bei horizontaler Rückenlage und im Stehen zu vergleichen. Die Studie wurde mit 20 unauffälligen Erstgebärenden im Verlauf der Wehentätigkeit durchgeführt, wobei die Kreißenden in Abständen von etwa 30 Minuten aus der horizontalen Rückenlage in den Stand und umgekehrt gebracht wurden. Die fetale Herzfrequenz und das Verhalten des intrauterinen Druckes wurde kontinuierlich aufgezeichnet. Die Weite des Muttermundes wurde alle 30 Minuten bestimmt. Die Patientinnen erhielten keine Medikamente. Die Frauen wurden angehalten zu sagen, wie groß jeweils in beiden Stellungen der wehenbedingte Schmerz war und welche Haltung sie als die angenehmere empfinden. Es wurde festgestellt:

1. Bei 15 von 20 Patientinnen war die Stärke der Kontraktionen signifikant größer beim aufrechten Stand (Figs. 1, 3).

2. Die Häufigkeit der Wehen verringerte sich im Stehen signifikant bei einem Drittel der Patientinnen (Fig. 4).
3. In der Hälfte der Fälle nahm die uterine Aktivität (Kontraktionsamplitude in $\mathrm{mmHg} \times$ Anzahl der Wehen während 10 Minuten) signifikant zu (Fig. 5).

4. In aufrechtem Stand war der die Wehen begleitende Schmerz durchweg geringer (Tab. II).

5. Darüber hinaus gaben die Patientinnen an, sich in dieser Haltung wohler zu fühlen (Tab. II).

Die mittlere Dauer der Wehentätigkeit von einer Muttermundsweite von 3 auf $10 \mathrm{~cm}$ betrug $3 \mathrm{Stdn} 55 \mathrm{~min}$ (Standardabweichung $1 \mathrm{Std} 40 \mathrm{~min}$ ). Diese Dauer ist kurz, wenn man sie mit der gängigen klinischen Erfahrung und mit von anderen Autoren publizierten Angaben [7] vergleicht.

Weder von seiten der Mutter noch von seiten des Feten waren Komplikationen zu beobachten bei der aufrechten Standhaltung während der Wehentätigkeit. Die physiologischen Mechanismen, die für die oben angeführten Einflüsse der Stehhaltung verantwortlich sind, sind unbekannt.

Die Schlußfolgerung ist, daß es keine klaren Argumente gegen die Anwendưng der Standhaltung sub partu gibt, daß im Gegenteil diese Haltung vielleicht häufiger in der täglichen geburtshilflichen Routine zur Anwendung kommen sollte, vorausgesetzt, daß die geburtshilflichen Bedingungen jenen entsprechen, die in dieser Arbeit mitgeteilt wurden (Erstgebärende, Schädellage, eingetretener Kopf).

Schlüsselwörter: Geburt (Dạer, Komplikationen), Haltung (mütterliche), intraamnialer Druck, Wehenschmerz, Wehentätigkeit (spontane). 


\section{Résumé}

Effets de la station debout sur la contractilité uterine spontanée et autres aspects du travail

Il a été prouvé que le changement de position de la mère peut avoir un effet sur la contractilité utérine et sur d'autres caractéristiques de l'accouchement $[4,6]$. Les effets de la position debout à ce point de vue ont été étudiés.

Le but de ce travail est de comparer la contractilité, la douleur produite par les contractions et le confort des patientes en position debout et en décubitus dorsal.

L'étude a été réalisée pendant la période de dilatation de vingt nullipares normales dont la position fut changée toutes les trente minutes environ. $\mathrm{La}$ pression intrauterine et la fréquence cardiaque foetale furent enregistrées de façon continue. La dilatation du col fut évaluée toutes les trente minutes. Aucune médication ne fut donnée aux patients. On leur demanda d'indiquer dans quelle position elles souffraient le plus lors des contractions.

Resultats:

1. Que l'intensité des contractions était néttement augmentée en position debout dans quinze sur les vingt patientes étudieés (Figs. 1, 3).

2. Leur fréquence diminua chez un tiers des patientes (Fig. 4).
3. L'activité utérine (intensité en $\mathrm{mmHg} \times$ nombre de contractions par dix minutes) augmenta dans $50 \%$ des cas (Fig. 5).

4. La douleur fut souvent atténuée en position debout (Tab. II).

5. Les patientes trouvèrent également cette position plus confortable (Tab. II).

La durée moyenne de dilatation $(3 \mathrm{à} 10 \mathrm{~cm}$ ) fut de 3 heures 55 minutes (écart type $=1$ heure 40 minutes). Cette durée est courte, si on la compare avec l'expérience clinique courante, et avec les publications d'autres auteurs [7].

On n'observa aucune complication maternelle ou foetale, au cours de ces accouchements en position debout.

Les mécanismes physiologiques responsables des effets liés à la position debout sont inconnus.

On conclut qu'il n'y a pas de contre indication à l'usage de là position debout pendant l'accouchement; au contraire, cette position devrait être plus fréquemment utilisée en obstétrique clinique, lorsque les conditions obstétrịcales sont les mêmes que cèlles présentées chez les patientes étudiées dans ce traviail (nulliparité, présentation céphalique engagée, etc.).

Mots-clés: Contractilité utérine, douleur du travail, durée du travail, dystocie, position maternelle, pression amniotique, travail spontanée.

\section{Bibliography}

[1] Alvarez, H., R. Caldeyro-Barcia: Contractility of the human uterus recorded by new methods. Surg., Gynec. and Obstet. 91 (1950) 1

[2] Arroyo, J., C. Mendez-Bauer: A practical approach to keep a stable "zero" level in intrauterine pressure, when changing maternal position. J. Perinat. Med. 3 (1975) 130

[3] Arroyo, J., A. Menéndez, C. Garcia-Ramos, F. Izquierdo, M. Lavilla, J. Villa Elizaga, J. Zamarriego, C. Méndez-Bauer: La posición de pié durante el trabajo de parto espantáneo. Clin. Invest. Gin. Obst. 1 (1974) 221

[4] Bösch, K., A. IkLE, O. KäsER: Fortlaufende Fruchtwasserdruckmessungen und simultane externe Tokodyamometrie sub partu. Schweiz. Med. Woch. 84 (1954) 850

[5] Caldeyro-Barcia, R., H. Alvarez, S. R. M. ReyNoLDs: A better understanding of uterine contractility through simultaneous recording with an internal and a seven channel external method. Surg., Gynec. and Obstet. 91 (1950) 641

[6] Caldeyro-Barcia, R., L. Noriega-Guerra, L. Cibils, H. Alvarez, J. J. Poseiro, S. Pose, Y. SicaBlanco, C. Mendez-Bauer, C. Fielitz, V. GonzalesPanizza: Effect of position changes on the intensity and frequency of uterine contractions during labor. Amer. J. Obstet. Gynec. 80 (1960) 284

[7] CiBrLs, L. A.: Enhancement and induction of labor. In: AlaDJEM, S.: Risks in the practice of modern obstetrics. Mosby, St. Louis, Missouri, 1972

[8] Lorand, von S., T. PoganY: Der Einfluß der Körperlage und des Lagewechsels auf die Wehentätigkeit. Gynaecología, 138:374, 1954

[9] Wirliams, A. E.: in Discussion to "Abnormal uterine action in labor". J. Obstet. Gynaec. Brit. Emp. 59 (1952) 635
Prof. Dr. C. Méndez-Bauer Dept. of Perinatal Research Maternidad Santa Cristina O’Donnell 55 Madrid 9/Spain 